\title{
Pseudocercospora mapelanensis sp. nov., associated with a fruit and leaf disease of Barringtonia racemosa in South Africa
}

\section{J. Alexander Osorio}

Department of Microbiology and Plant Pathology, DST/NRF Centre of Excellence in Tree Health Biotechnology (CTHB), Forestry and Agricultural Biotechnology Institute (FABI), University of Pretoria, Private Bag X20, Pretoria, 0028, South Africa.

\section{Michael J. Wingfield}

Department of Microbiology and Plant Pathology, DST/NRF Centre of Excellence in Tree Health Biotechnology (CTHB), Forestry and Agricultural Biotechnology Institute (FABI), University of Pretoria, Private Bag X20, Pretoria, 0028, South Africa.

\section{Z. Wilhelm de Beer}

Department of Microbiology and Plant Pathology, DST/NRF Centre of Excellence in Tree Health Biotechnology (CTHB), Forestry and Agricultural Biotechnology Institute (FABI), University of Pretoria, Private Bag X20, Pretoria, 0028, South Africa.

\section{Jolanda Roux*}

Department of Microbiology and Plant Pathology, DST/NRF Centre of Excellence in Tree Health Biotechnology (CTHB), Forestry and Agricultural Biotechnology Institute (FABI), University of Pretoria, Private Bag X20, Pretoria, 0028, South Africa.

Jolanda.Roux@fabi.up.ac.za

\begin{abstract}
Barringtonia racemosa (Lecythidaceae) is a widely distributed mangrove associate in coastal areas of Africa, Asia and Australia. During routine disease surveys along the east coast of the KwaZulu-Natal Province in South Africa, B. racemosa trees were observed showing symptoms of leaf infection and necrotic lesions on fruits. A previously undescribed species of Pseudocercospora was commonly associated with these symptoms.
\end{abstract}


This fungus is described as Pseudocercospora mapelanensis sp. nov., based on multi-gene sequence analyses of the ACT, ITS, LSU and TEF genome regions, as well as morphological characteristics.

Key Words: Capnodiales, Lecythidaceae, Mangroves, Mycosphaerellaceae

\section{INTRODUCTION}

Mangroves, including true mangroves and mangrove associates (Tomlinson 1986; Ellison and Farnsworth 2001; Kathiresan and Bingham 2001; Hogarth 2007; Wang et al. 2010), are adapted to survive in saline-rich water and anoxic soils. They are found along tropical and subtropical coastlines where they provide many environmental and economic benefits (Spalding et al. 2010). Mangroves are, however, frequently threatened by anthropogenic activities and/or environmental factors (Spalding 2010). Despite their importance there have been relatively few studies to consider the impact of microbial diseases on these trees (Osorio et al. 2014). Diseases that have been reported from mangroves include branch cankers, leaf spots and die-back of trees (Barnard and Freeman 1982; Teas et al. 1982; Wier et al. 2000; Tattar and Scott 2004; Osorio et al. 2014).

Barringtonia racemosa (L.) Spreng. (powder-puff tree, fresh water mangrove) is a mangrove associate that belongs to the family Lecythidaceae, found along canals and rivers of coastal areas of Africa, Asia and Australia (Chantaranothai 1995; USDA-ARS 2014). Barringtonia racemosa trees are valuable as a source of medicinal products, timber, food and tannin (Lim 2012). Although several fungal species have been reported from Barringtonia species globally, nothing is known regarding fungal pathogens of $B$. racemosa in South Africa. During a survey of the health of mangrove species in this country, a fruit, floral and leaf disease was observed on B. racemosa trees in the Zululand 
region. The aim of this study was to describe the symptoms of the disease and to identify its causal agent.

\section{Materials and Methods}

\section{Disease observations and sample collection}

In February 2011, a disease affecting the flowers, fruits and leaves of Barringtonia racemosa was observed in the Mapelane area of the Kwazulu-Natal Province in South Africa. In order to identify the fungus most closely associated with the disease symptoms, infected fruits, floral sepals and leaves were collected from several sites, placed in paper bags and transported to the laboratory for further study. During 2012 and 2013, additional areas where $B$. racemosa is known to occur were also surveyed for the occurrence of the disease, and additional samples were collected for analyses.

\section{Cultures}

A single fungus was found sporulating profusely on infected green leaf and fruit tissue. Fungal structures were transferred directly from plant material, mounted on microscope slides and examined under a Zeiss Axioskop microscope (Carl Zeiss, Germany). Images were obtained by using an Axiocam digital camera connected to the microscope. To isolate this fungus, stromatic tissue was removed from symptomatic plant material and transferred to $500 \mu \mathrm{l}$ autoclaved Sabax water. Of this, $100 \mu \mathrm{l}$ were spread onto $2 \%$ malt extract agar (MEA, Biolab Malt Extract, 17g Biolab Agar amended with $0.4 \mathrm{~g}$ of streptomycin to suppress bacterial growth, in 1L distilled water) and incubated overnight. Germinating conidia were transferred to fresh $2 \%$ MEA. Pure cultures obtained from single spore isolates were deposited in the culture collection (CMW) of the Tree Protection Cooperative Programme (TPCP) at FABI, University of Pretoria. Duplicate cultures were 
deposited in the CBS-KNAW Fungal Biodiversity Centre's culture collection (Centraalbureau voor Schimmelcultures) in Utrecht, The Netherlands.

\section{Pathogen Identification}

DNA Extraction, PCR Amplification and Sequencing

To extract genomic DNA, mycelium from colonies of three isolates, no older than four weeks of age, were placed into $1.5 \mathrm{~mL}$ sterile Eppendorf tubes and freeze dried. Isolates for identification were selected based on plant part and collection site, so as to represent all symptom types and regions, as well as multiple trees. DNA was extracted using the phenol-Chloroform method described by Raeder and Broda (1985). After DNA was obtained, a NanoDrop ND-1000 spectrophotometer (NanoDrop Technologies, Rockland, DE) was used to measure DNA concentrations, and to calculate the volumes to be used in PCR reactions.

Four gene regions were sequenced for all isolates. A portion of the mitochondrial large subunit (LSU) was amplified using primers LR5 (Vilgalys and Hester 1990) and LR0R (Moncalvo et al. 1993). The internally transcribed spacer (ITS) regions (ITS1, ITS2) were amplified using the primers ITS1 and ITS4 (White et al. 1990). A portion of the translation elongation factor 1- $\alpha$ (TEF) was amplified using the primers EF1F and EF2R (Jacobs et al. 2004). A portion of the actin (ACT) gene was amplified using the primers ACT-512F and ACT-783R (Carbone and Kohn 1999).

For all gene regions, each reaction contained $2.5 \mu \mathrm{L}$ of PCR buffer, $2 \mu \mathrm{L}$ dNTP, $1 \mu \mathrm{L}$ of each primer, $0.3 \mu \mathrm{L}$ of fast $T a q$ polymerase and $3 \mu \mathrm{L}$ of DNA $(60 \mathrm{ng} / \mu \mathrm{l})$. Sterile Sabax water was added to obtain a final volume of $25 \mu \mathrm{L}$ for each reaction. Reactions were run using the following thermal cycling conditions: initial denaturation at $94^{\circ} \mathrm{C}$ for four minutes 
followed by a denaturation step of ten cycles consisting of $94^{\circ} \mathrm{C}$ for 20 seconds, annealing at $55^{\circ} \mathrm{C}$ (ITS and TEF), $48^{\circ} \mathrm{C}$ (LSU) and $61^{\circ} \mathrm{C}$ (ACT) for 48 seconds, and elongation at $72^{\circ} \mathrm{C}$ for 45 seconds, followed by a further 25 cycles of $94^{\circ} \mathrm{C}$ for 20 seconds, followed by an annealing step with temperatures as previously indicated for each gene region $\left(55^{\circ} \mathrm{C}\right.$, $48^{\circ} \mathrm{C}, 61^{\circ} \mathrm{C}$ ), for 40 seconds with a time increase of five seconds per cycle, and then 45 seconds at $72^{\circ} \mathrm{C}$. This was concluded by a final step of $72^{\circ} \mathrm{C}$ for 10 minutes. An aliquot of five $\mu l$ of each PCR product was separated by gel electrophoresis at $90 \mathrm{~V}$ for $20 \mathrm{~min}$ in a $2 \%$ agarose gel in 5\% TAE Buffer (40 mM Tris, $40 \mathrm{mM}$ acetate, $2 \mathrm{mM}$ EDTA, $\mathrm{pH}$ 8.0) to evaluate the success of the reactions using GelRedTM nucleic acid gel stain (Biotium, Hayward, CA, USA). PCR products were cleaned using Sephadex G-50 columns, following the instructions provided by the manufacturers (Sigma Aldrich, Sweden).

Purified PCR products were used as template DNA for sequencing reactions, using a BigDye terminator cycle sequencing kit (Perkin-Elmer Applied Biosystems, Foster City, California, USA) and the same primers and annealing temperatures that were used in the PCR. The final products were also cleaned in Sephadex G-50 columns. Sequencing was carried out on an ABI PRISM 3100 DNA sequencer (Applied Biosystems).

\section{Morphology}

Colony morphology and microscopic features of the isolated fungus were examined directly from plant material and from cultures growing on 2\% MEA. Mounts of the fungus were prepared in $85 \%$ lactic acid on microscope slides for detailed observations of structures such as stromata, conidiophores and conidia. Where structures were dry, these were mounted in $2 \% \mathrm{KOH}$. Characters such as size of conidiophores and conidiogenous cells as well as pigmentation of the conidia were used for description of the species based on morphology. Fifty measurements were made for each relevant morphological 
characteristic and the standard deviation (S.D.) was calculated for measurements of the stromata, conidia and conidiophores. Minimum and maximum dimensions are given in parentheses.

Colony colors (surface and reverse) were assessed after 30 days on MEA, using the color chart of Rayner (1970). Growth of cultures was assessed by measuring single conidial cultures after 15,30 and 60 days maintained at a temperature of $25^{\circ} \mathrm{C}$. Culture characteristics were determined from cultures grown under natural day/night conditions.

\section{Phylogenetic analyses}

Sequences of the isolates obtained from B. racemosa were assembled using CLC Main Workbench 6.7.1 (http://www.clcbio.com/genomics/), and compared with published sequences using a Blast search in the GenBank (http://blast.ncbi.nlm.nih.gov/blast.cgi) data base. DNA sequences for closely related species, previously published, were retrieved from GenBank and combined into data sets with the B. racemosa sequences (Table 1). The data matrices were aligned online using MAFFT (http://align.bmr.kyushuu.ac.jp/mafft/online/server/) version 6 (Katoh et al. 2005) and edited manually for alignment errors with MEGA version 6 (Tamura et al. 2013).

Phylogenetic analyses of sequence data for Maximum Parsimony (MP) were performed with the software package PAUP* $4.0 \mathrm{~b} 10$ (Swofford 2003). Maximum parsimony (MP) genealogies for single genes were constructed with the heuristic search option (1000 random taxa additions, tree bisection and reconstruction or TBR in PAUP). Uninformative characters in each data set were excluded from the analyses, and the consistency index (CI), homoplasy index (HI), rescaled consistency index (RC), retention index (RI) and tree length (TL) were determined for the resulting trees. Partition homogeneity tests (PHT) were conducted to determine the congruence of trees obtained from the different gene 
regions with PAUP* 4.0b10 (Swofford 2003) to define whether data from the different gene regions could be combined.

Phylogenetic analyses of sequence data for Maximum Likelihood (ML) were performed with the program PhyML version 3.0 (Guindon and Gascuel 2003). The confidence levels were estimated with 1000 bootstrap replicates. The best fit substitution models for each of the data combinations were determined using jModeltest 0.1.1 (Posada 2008). MrBayes v. 3.2 (Ronquist et al. 2012) was implemented to perform the Bayesian inference (BI) analyses. Trees were sampled at every 100th generation for six million generations and the posterior probability values above 0.95 were accepted.

\section{Results}

Disease symptoms and sample collection

The fruit, leaf and floral sepal disease of B. racemosa was found in the Mapelane area on the southern border of the Isimangaliso Wetland Park, the city of Richards Bay and in Mlalazi Nature Reserve near the town of Mtunzini. Symptoms were mostly observed during summer, particularly January to April. Isolates of the fungus consistently associated with this disease were obtained from the aerial organs of ten trees from Mapelane, as well as from ten trees each in two areas in Richards Bay. Three representative isolates from fruits, leaves and sepals were selected for identification based on DNA sequence data.

The disease affecting B. racemosa was characterized by sooty black spots on the fruits (Fig. 1A, 1B); on the floral sepals (1C, 1D) as well as dark stromata becoming confluent to produce large spots on the leaves (Fig. 1E, 1F). These spots could merge and cover the entire surface of the aerial organs affected. Leaf infection often resulted in leaf 

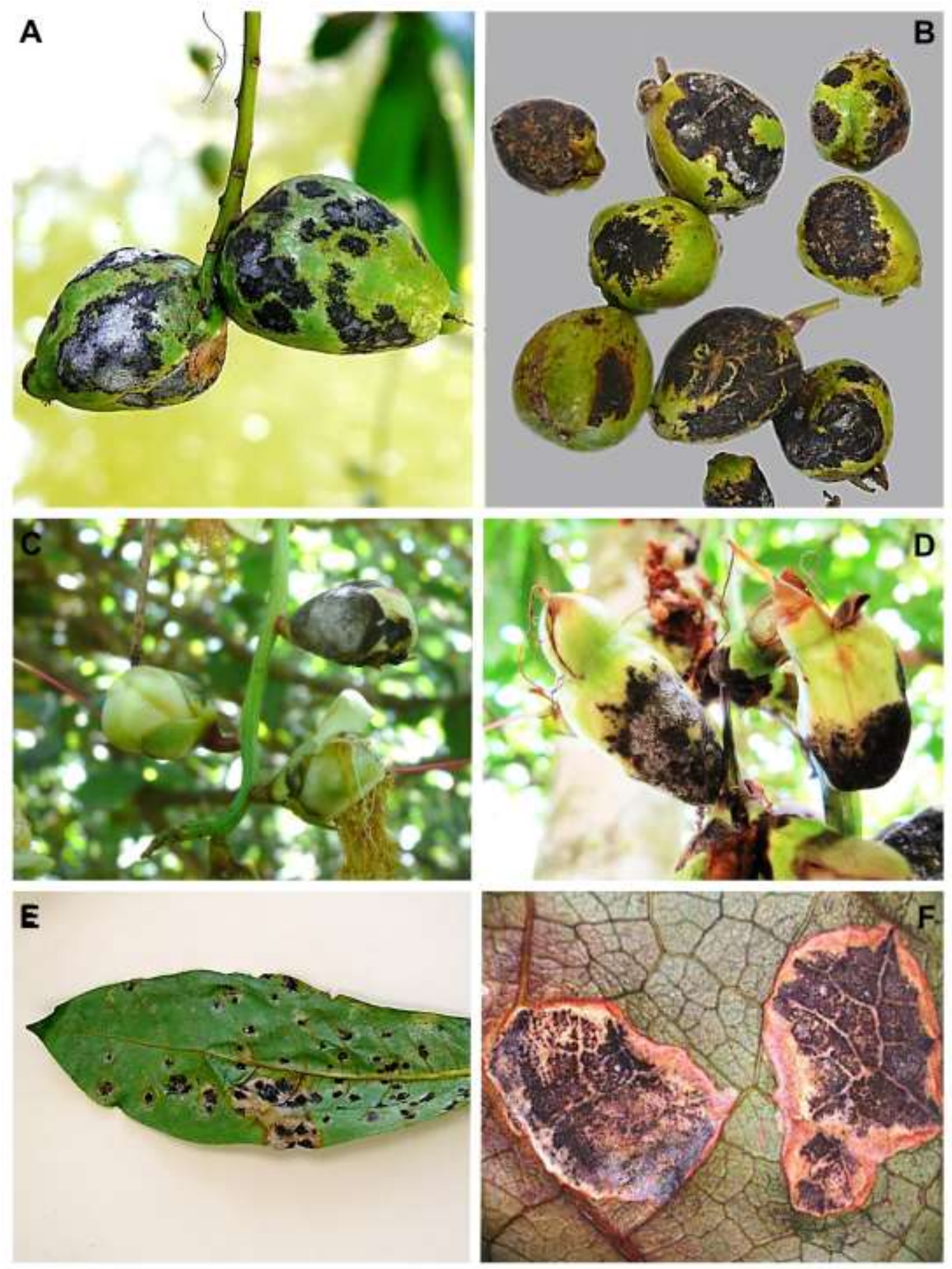

Fig. 1 Signs and symptoms of disease caused by Pseudocercospora mapelanensis on B. racemosa (A, B). Fruit disease caused by $P$. mapelanensis (C, D). Sooty black spots on floral sepals (E). Leaf spots on the abaxial part of the leaf $(\mathbf{F})$. Close up of leaf spots caused by $P$. mapelanensis. 

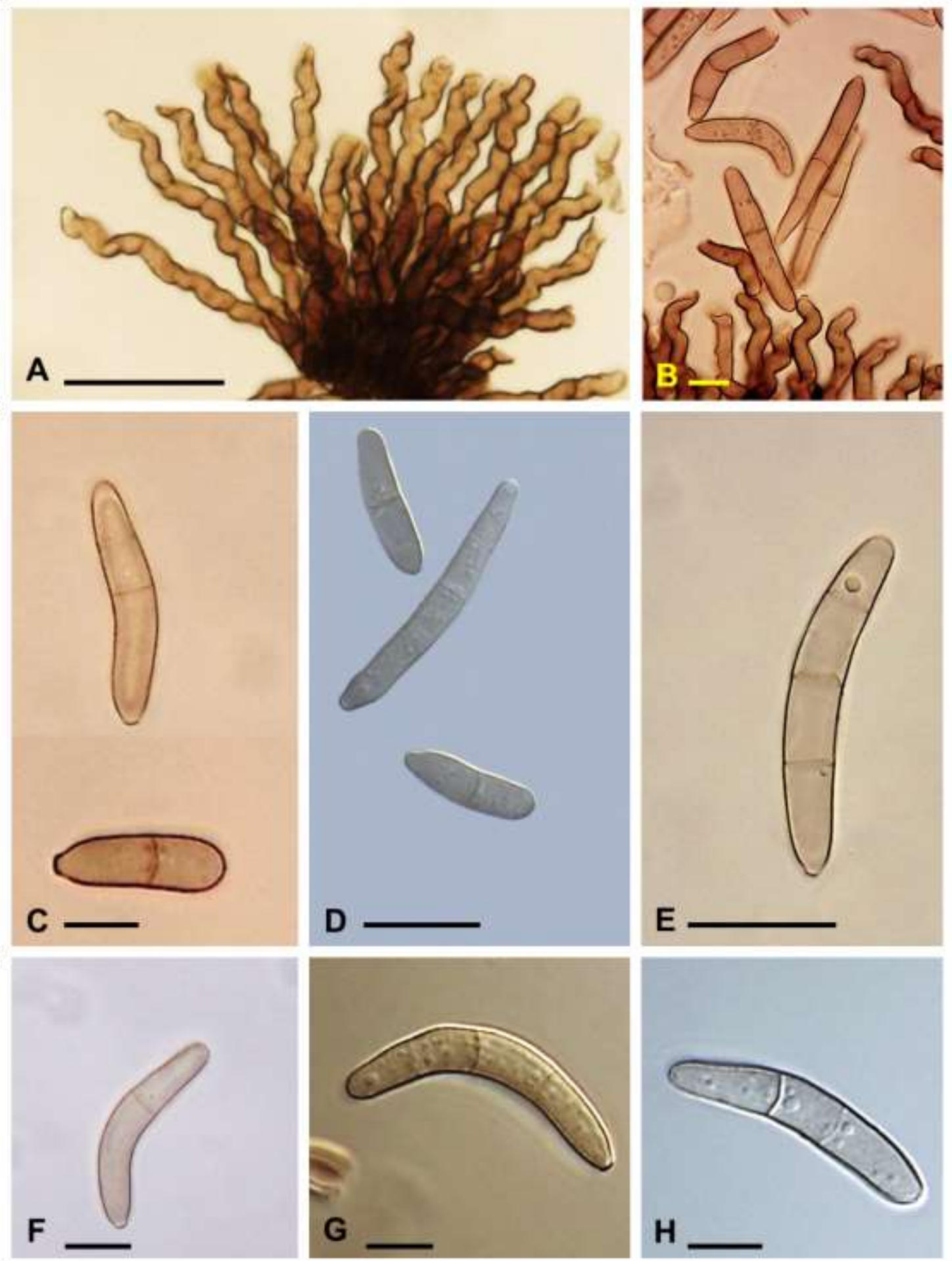

Fig. 2 Conidiophores and conidia of Pseudocercospora mapelanensis (A). Geniculate conidiophores, observed with zoom (40x) bar $(50 \mu \mathrm{m})$. (B) Conidiophores and conidia observed with zoom (40x) (bar $10 \mu \mathrm{m})$. (C, D, E, F, G, H) Pale brown conidia with truncate base, different shape, length and septa observed with zoom (100x) (bar C, F, G, H $=10 \mu \mathrm{m})$, (bar $\mathbf{D}, \mathbf{E}=20 \mu \mathrm{m})$. 
deformation (Fig. 1E). Brownish conidiophores and pale brown conidia were commonly observed under the microscope (Fig. 2). Although the disease did not result in defoliation of trees, flower and fruit abortion was common on affected trees at Mapelane and Richards Bay.

\section{Identification}

\section{PCR Amplification and Sequencing}

DNA was successfully extracted from the isolates and PCR and sequence products generated for all selected gene regions. Sequence fragments were approximately $367 \mathrm{bp}$ in size for the ACT, 485bp for the ITS, 826bp for the LSU and 456bp for the TEF-1 $\alpha$. All sequences used in this study have been deposited in GenBank (Table 1).

\section{Phylogenetic analyses}

Blast searches in Genbank, of sequences generated for the LSU and ITS gene regions, showed that all isolates obtained from diseased B. racemosa represented a species of Pseudocercospora. Based on these results, data sets were assembled for all gene regions sequenced, including sequence data for previously described, published species of Pseudocercospora (Table 1).

Sequence data sets of the ACT, ITS, LSU, and TEF-1 $\alpha$ gene regions were analyzed individually (Table 1). A phylogenetic re-construction was conducted for the aligned LSU data set to determine generic relationships. The LSU data set comprised species from the five closest related sister genera in the Mycosphaerellaceae, based on Blast searches and published literature. These included Cercospora Fresen., Mycosphaerella Johanson., Passalora Fresen., Pseudocercospora Speg., Septoria Sacc., and Pallidocercospora Crous. 
Table 1 Isolates included in phylogenetic analyses. Accession numbers of DNA sequences generated in the present study are printed in bold.

\begin{tabular}{|c|c|c|c|c|c|c|c|c|}
\hline \multirow[t]{2}{*}{ Species } & \multirow[t]{2}{*}{ Isolate No } & \multirow[t]{2}{*}{ Collector } & \multirow[t]{2}{*}{ Host } & \multirow[t]{2}{*}{ Country } & \multicolumn{4}{|c|}{ GenBank Accession Numbers } \\
\hline & & & & & LSU & ITS & TEF-1- $\alpha$ & ACT \\
\hline Cercospora capsici & CBS118712 & P. Tyler & Unknown & Fiji & GU214653 & & & \\
\hline C. sojina & CPC12322 & H.D. Shin & Glycine soja & South Korea & GU253861 & & & \\
\hline $\begin{array}{l}\text { Cladosporium } \\
\text { cladosporioides }\end{array}$ & CBS 10921 & & & & EU019262 & & & \\
\hline C. herbarum & AFTOL-ID 1591 & & & & DQ678074 & & & \\
\hline Mycosphaerella africana & CMW4945 & P.W Crous & Eucalyptus viminalis & South Africa & DQ246257 & & & \\
\hline M. ellipsoidea & CMW4934 & Unknown & Eucalyptus sp. & South Africa & DQ246253 & & & \\
\hline M. madeirae & CBS112895 & S. Denman & E. globulus & Portugal & DQ204756 & & & \\
\hline M. laricina & CBS326.52 & E. Müller & Larix decidua & Switzerland & GU253693 & & & \\
\hline $\begin{array}{l}\text { Pallidocercospora } \\
\text { acaciigena }\end{array}$ & СРC3838 & M.J. Wingfield & Acacia mangium & Venezuela & GU214661 & & & \\
\hline Pal. crystallina & CMW3033 & M.J. Wingfield & E. bicostata & South Africa & DQ204747 & & & \\
\hline Pal. heimii & CMW4942 & P.W. Crous & Eucalyptus sp. & Madagascar & DQ204751 & & & \\
\hline Pal. heimioides & CMW3046 & M.J. Wingfield & Eucalyptus sp. & Indonesia & DQ204753 & & & \\
\hline Pal. irregulariramosa & CMW4943 & M.J. Wingfield & E. saligna & South Africa & DQ204754 & & & \\
\hline Pal. konae & CBS120748 & W. Himamam & E. camaldulensis & Thailand & GU253852 & & & \\
\hline Passalora eucalypti & CBS111318 & P.W. Crous & E. saligna & Brazil & GU253860 & GU269845 & GU384558 & GU320548 \\
\hline $\begin{array}{l}\text { Pseudocercospora } \\
\text { abelmoschi }\end{array}$ & CPC14478 & H.D. Shin & Hibiscus syriacus & South Korea & GU253696 & GU269647 & GU384365 & GU320355 \\
\hline P. acericola & CBS122279 & R. Kirschner & Acer albopurpurascens & Taiwan & GU253699 & GU269650 & GU384368 & GU320358 \\
\hline P. ampelopsis & CPC11680 & H.D. Shin & $\begin{array}{l}\text { Ampelopsis } \\
\text { brevipenduncula }\end{array}$ & South Korea & GU253846 & GU269830 & GU384542 & GU320534 \\
\hline P. angolensis & CBS14953 & M.C. Pretorius & Citrus sp. & Zimbabwe & JQ324941 & JQ324975 & GU384548 & JQ325010 \\
\hline P. arecacearum & CBS118406 & C.F. Hill & Rhopalostylis sapidis & New Zealand & GU253704 & GU269655 & GU384373 & GU320363 \\
\hline P. atromarginalis & CBS114640 & C.F. Hill & Solanum sp. & New Zealand & GU253706 & GU269658 & GU384376 & GU320365 \\
\hline P. avicenniae & $\begin{array}{l}\text { MycoBank: } \\
\text { MB515468 }\end{array}$ & $\begin{array}{l}\text { R.G. Shivas \& P.W. } \\
\text { Crous }\end{array}$ & Avicennia marina & Australia & & & & \\
\hline P. chengtuensis & CPC10696 & H.D. Shin & Lycium chinense & South Korea & JQ324942 & GU269673 & GU384390 & GU320379 \\
\hline P. cladosporioides & CBS117482 & P.W. Crous & Olea europaea & Tunisia & JQ324944 & GU269678 & GU384395 & GU320383 \\
\hline P. coprosmae & CBS114639 & C.F. Hill & Coprosma robusta & New Zealand & JQ324946 & GU269680 & GU384397 & GU320386 \\
\hline
\end{tabular}




\begin{tabular}{|c|c|c|c|c|c|c|c|c|}
\hline \multirow[t]{2}{*}{ Species } & \multirow[t]{2}{*}{ Isolate No } & \multirow[t]{2}{*}{ Collector } & \multirow[t]{2}{*}{ Host } & \multirow[t]{2}{*}{ Country } & \multicolumn{4}{|c|}{ GenBank Accession Numbers } \\
\hline & & & & & LSU & ITS & TEF-1- $\alpha$ & ACT \\
\hline P. crispans & CPC14883 & P.W. Crous & Eucalyptus sp. & South Africa & GU253825 & GU269807 & GU384518 & GU320510 \\
\hline P. cruenta & CPC10846 & H. Booker & Vigna sp. & Trinidad & GU269688 & GU269688 & GU384404 & JQ325012 \\
\hline P. cydoniae & CPC10678 & H.D. Shin & Chaenomeles speciosa & South Korea & GU253732 & GU269691 & GU384407 & GU320396 \\
\hline P. dodonaeae & CBS114647 & C.F. Hill & Dodonaea viscosa & New Zealand & JQ324948 & GU269697 & GU384413 & JQ325013 \\
\hline P. dovyalidis & CPC13771 & P.W. Crous & Dovyalis zeyheri & South Africa & GU253818 & GU269800 & GU384513 & GU320503 \\
\hline P. eucalyptorum & CPC10916 & P.W. Crous & Eucalyptus sp. & South Africa & GU253788 & & & \\
\hline P. eustomatis & CBS110822 & G. Dal Bello & Eustroma grandiflorum & Argentina & GU253744 & GU269705 & GU384421 & GU320409 \\
\hline P. fori & CMW9095 & G.C. Hunter & E. grandis & South Africa & DQ204748 & AF468869 & DQ211664 & DQ147618 \\
\hline$P$. fraxinites & CPC10743 & H.D. Shin & $\begin{array}{l}\text { Fomtanesia } \\
\text { phillyraeoides }\end{array}$ & South Korea & GU253720 & GU269672 & GU384389 & GU320378 \\
\hline P. fuligena & CPC12296 & Z. Mersha & Lycopersicon sp. & Thailand & JQ324953 & GU269711 & GU384427 & GU320415 \\
\hline P. hakeae & CBS112226 & $\begin{array}{l}\text { P.W. Crous \& B. } \\
\text { Summerell }\end{array}$ & Grevillea sp. & Australia & GU253805 & GU269784 & GU384495 & JQ325017 \\
\hline P. humulicola & CPC10049 & H.D. Shin & Humulus scandens & South Korea & JQ324955 & GU269724 & JQ324996 & JQ325018 \\
\hline P. mapelanensis & CMW40579 & J.A. Osorio \& J. Roux & B. racemosa & South Africa & KM203119 & KM203116 & KM203122 & KM203125 \\
\hline P. mapelanensis & CMW40580 & J.A. Osorio \& J. Roux & B. racemosa & South Africa & KM203120 & KM203117 & KM203123 & KM203126 \\
\hline P. mapelanensis & CMW40581 & J.A. Osorio \& J. Roux & B. racemosa & South Africa & KM203121 & KM203118 & KM203124 & KM203127 \\
\hline P. indonesiana & CBS122473 & I.W. Buddenhagen & Musa sp. & Sumatra & GU253765 & GU269735 & GU384448 & GU320437 \\
\hline P. kiggelariae & CPC11853 & W. Gams & Kiggelaria africana & South Africa & GU253762 & GU269730 & GU384443 & GU320432 \\
\hline P. libertiae & CBS114643 & C.F. Hill & Libertia ixioides & New Zealand & JQ324959 & GU269733 & GU384446 & GU320435 \\
\hline P. longispora & CBS122470 & D.R. Jones & Musa sp. & Malaysia & GU253764 & GU269734 & GU384447 & GU320436 \\
\hline P. luzardii & СРC2556 & A.C. Alfenas & Hancornia speciosa & Brazil & GU214477 & GU269738 & GU384450 & GU320440 \\
\hline P. musae & CBS116634 & J. Carlier & Musa sp. & Cuba & GU253775 & & & \\
\hline P. oenotherae & CPC10290 & H.D. Shin & Oenothera odorata & South Korea & JQ324961 & GU269856 & GU384567 & GU320559 \\
\hline P. plectranthi & CPC11462 & H.D. Shin & Plectranthus sp. & South Korea & JQ324962 & GU269791 & GU384501 & GU320492 \\
\hline P. proteae & CPC15217 & F. Roets & Protea mundii & South Africa & GU253826 & GU269808 & GU384519 & GU320511 \\
\hline P. prunicola & CPC14511 & H.D. Shin & Prunus x yedoensis & South Korea & GU253723 & GU269676 & GU384393 & GU320382 \\
\hline P. punctata & CPC14734 & P.W. Crous & Syzygium sp. & Madagascar & GU253791 & GU269765 & GU384477 & GU320468 \\
\hline$P$. ranjita & CPC11141 & M.J. Wingfield & Gmelina sp. & Indonesia & GU253810 & GU269790 & GU384500 & GU320491 \\
\hline
\end{tabular}




\begin{tabular}{|c|c|c|c|c|c|c|c|c|}
\hline \multirow[t]{2}{*}{ Species } & \multirow[t]{2}{*}{ Isolate No } & \multirow[t]{2}{*}{ Collector } & \multirow[t]{2}{*}{ Host } & \multirow[t]{2}{*}{ Country } & \multicolumn{4}{|c|}{ GenBank Accession Numbers } \\
\hline & & & & & LSU & ITS & TEF-1- $\alpha$ & ACT \\
\hline P. ravenalicola & CBS122468 & M. Arzanlou \& W. Gams & $\begin{array}{l}\text { Ravenala } \\
\text { madagascariensis }\end{array}$ & India & GU253828 & GU269810 & GU384521 & GU320513 \\
\hline P. rhoina & CPC11464 & H.D. Shin & Rhus chinensis & South Korea & JQ324966 & & & \\
\hline P. rubi & MUCC875 & $\begin{array}{l}\text { T. Kobayashi \& C. } \\
\text { Nakashima }\end{array}$ & Rubus allegheniensis & Japan & GU253795 & GU269773 & GU384485 & GU320476 \\
\hline P. rumohrae & CBS117747 & C.F. Hill & Marattia salicina & New Zealand & GU253796 & GU269774 & GU384486 & GU320477 \\
\hline P. subsessilis & CBS136.94 & R.F. Castaneda & & Cuba & GU253832 & GU269815 & GU384527 & GU320517 \\
\hline P. subtorulosa & CBS117230 & R. Kirschner & Melicope sp. & Taiwan & GU253833 & & & \\
\hline P. tereticornis & CBS124996 & A.J. Carnegie & E. nitens & Australia & GQ852647 & & & \\
\hline P. timorensis & MUCC 819 & $\begin{array}{l}\text { C. Nakashima \& T. } \\
\text { Akashi }\end{array}$ & Ipomoea indica & Japan & GU253840 & GU269823 & GU384536 & GU320526 \\
\hline$P$. viticicola & MUCC777 & C. Nakashima & Vitex trifolia & Japan & GU253845 & GU269828 & GU384540 & GU320532 \\
\hline P. vitis & CPC11595 & H.D. Shin & V. vinifera & South Korea & GU214483 & GU269829 & GU384541 & GU320533 \\
\hline P. xanthocercidis & CPC11665 & A.R. Wood & $\begin{array}{l}\text { Xanthocercis } \\
\text { zambesiaca }\end{array}$ & South Africa & JQ324971 & & & \\
\hline P. xanthoxyli & CPC10065 & H.D. Shin & Xanthoxylum ailathoides & South Korea & GU253848 & GU269832 & GU384544 & GU320536 \\
\hline Septoria cerastii & CPC12343 & H.D. Shin & $\begin{array}{l}\text { Cerastium holosteoides } \\
\text { var. hallasanense }\end{array}$ & South Korea & GU253869 & & & \\
\hline S. chelidonii & CPC12337 & H.D. Shin & $\begin{array}{l}\text { Chelidoniummajur var. } \\
\text { asiaticum }\end{array}$ & South Korea & GU253870 & & & \\
\hline S. crepidis & CPC12539 & H.D. Shin & Crepis japonica & South Korea & GU253871 & & & \\
\hline S. dysentericae & CPC12328 & H.D. Shin & $\begin{array}{l}\text { Inula britannica var. } \\
\text { chinensis }\end{array}$ & South Korea & GU253866 & & & \\
\hline S. erigerontis & CPC12340 & H.D. Shin & Erigeron annuus & South Korea & GU253872 & & & \\
\hline S. eucalyptorum & CPC11282 & W. Gams & Eucalyptus sp. & India & GU253873 & & & \\
\hline S. justiciae & CPC12509 & H.D. Shin & Justicia procumbens & South Korea & GU253874 & & & \\
\hline S. quercicola & CBS663.94 & H.A. Van der Aa & Querqus robur & Netherlands & GU253867 & & & \\
\hline
\end{tabular}

CBS: Centraalbureau,voor Schimmelcultures, CBS-KNAW Fungal Biodiversity Centre, Utrecht, The Netherlands; CMW: Culture Collection of the Forestry and Agricultural Biotechnology Institute (FABI), University of Pretoria, Pretoria, South Africa; MUCC Murdoch University Algal Culture Collection, Murdoch, Western Australia; CPC Collection of Pedro Crous housed at CBS.

LSU: partial 28S nrRNA gene; ITS: internal transcribed spacer regions $1 \& 2$ including 5.8S nrRNA gene; EF-1 $\alpha$ : partial translation elongation factor 1-alpha gene; ACT: partial actin gene. 

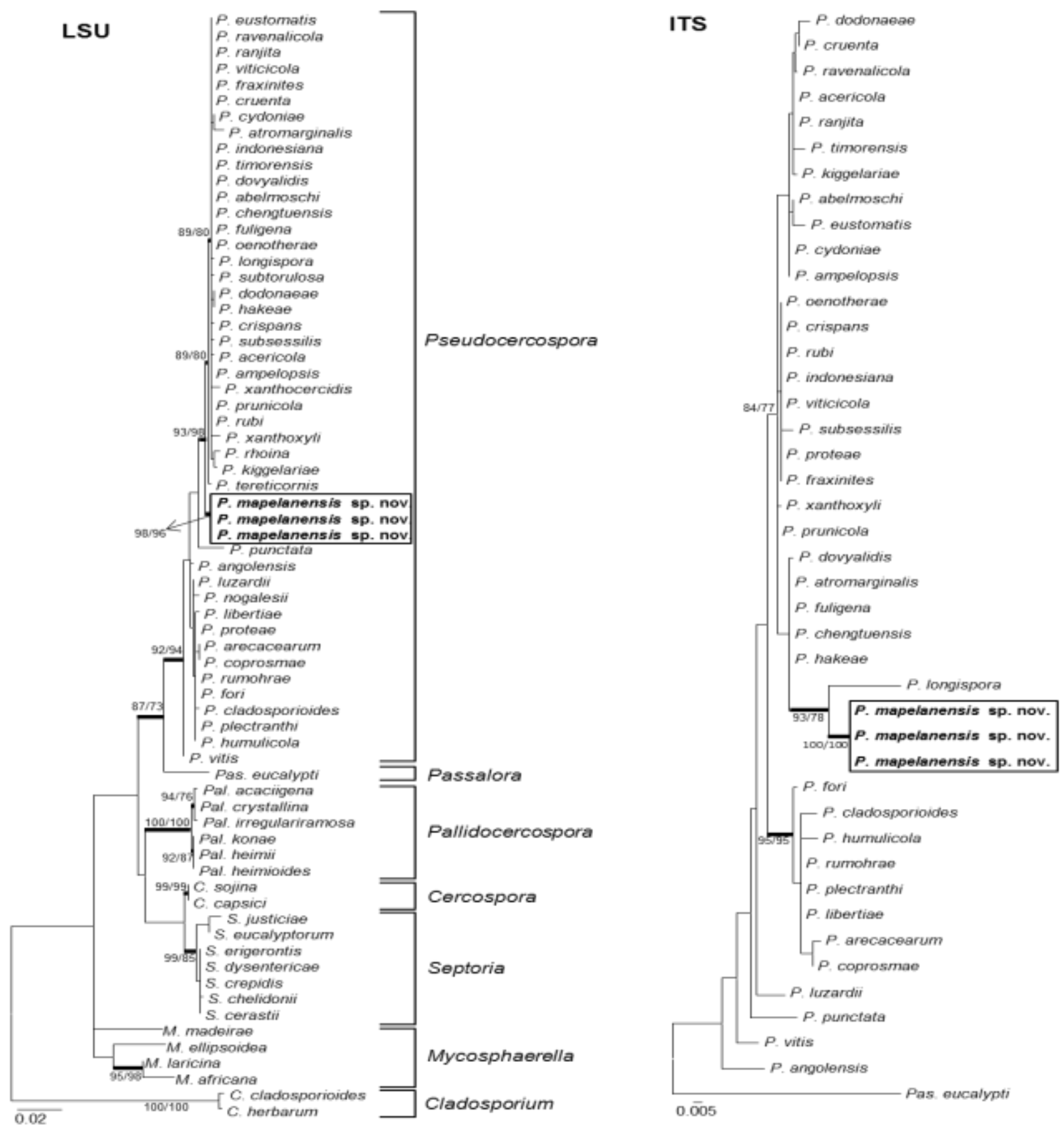

Fig. 3 Phylograms obtained from (BI), (ML) and (MP) analyses of the LSU and ITS data sets. These analyses provide evidence of isolates obtained from B. racemosa grouping into the Pseudocercospora clade, indicated in the LSU tree. The ITS analyses suggest that isolates from $B$. racemosa represent an undescribed species, with $P$. longispora as the most closely related species to $P$. mapelanensis sp. nov., (BI) posterior probabilities $\geq 95 \%$ are represented by thick branches. Bootstrap support values $>70 \%$ are indicated near the nodes as MP/ML. * $=$ bootstrap support values $<70 \%$. 
Cladosporium cladosporioides (Fresen.) G.A. de Vries., and Cladosporium herbarum (Pers.) Link, were included as outgroups. The dataset for the LSU phylogenetic analyses comprised a total of 69 taxa. ML analyses resulted in 1000 trees and MP analyses in 7304 trees (Fig. 3).

The isolates obtained from $B$. racemosa grouped strongly within the genus Pseudocercospora in all analyses. Subsequently, a species level phylogeny was derived from individual analysis of the ACT, ITS and TEF-1 $\alpha$ alignment of described species of Pseudocercospora, with Passalora eucalypti (Crous \& Alfenas) Crous \& U. Braun, included as outgroup. A total of 43 taxa were included in the analyses for each of the three gene regions. ML analyses of the ITS data set resulted in 1000 trees and MP analyses in 93765 trees. These trees all suggested that isolates from B. racemosa represent an undescribed species, most closely related to, but distinct from, P. longispora (Fig. 3).

Phylogenetic analyses involving sequence data from the ACT and TEF gene regions helped to clarify the placement of the species from B. racemosa (Fig. 4). ML analysis of the ACT gene region resulted in 1000 trees and MP analysis in 4274 trees. The ML analysis of the TEF gene region data set resulted in 1000 trees and MP analysis in 156 trees. These trees also suggested that isolates from $B$. racemosa represent an undescribed species of Pseudocercospora, showing $P$. dodonaeae as the closest relative in the ACT gene region and $P$. xanthoxyli as the closest relative in the TEF-1 $\alpha$ gene region.

\section{Taxonomy}

Based on sequence comparisons for multiple gene regions, the fungus obtained from diseased B. racemosa in South Africa represents an undescribed species of Pseudocercospora. We provide the following description based on morphological characteristics. 

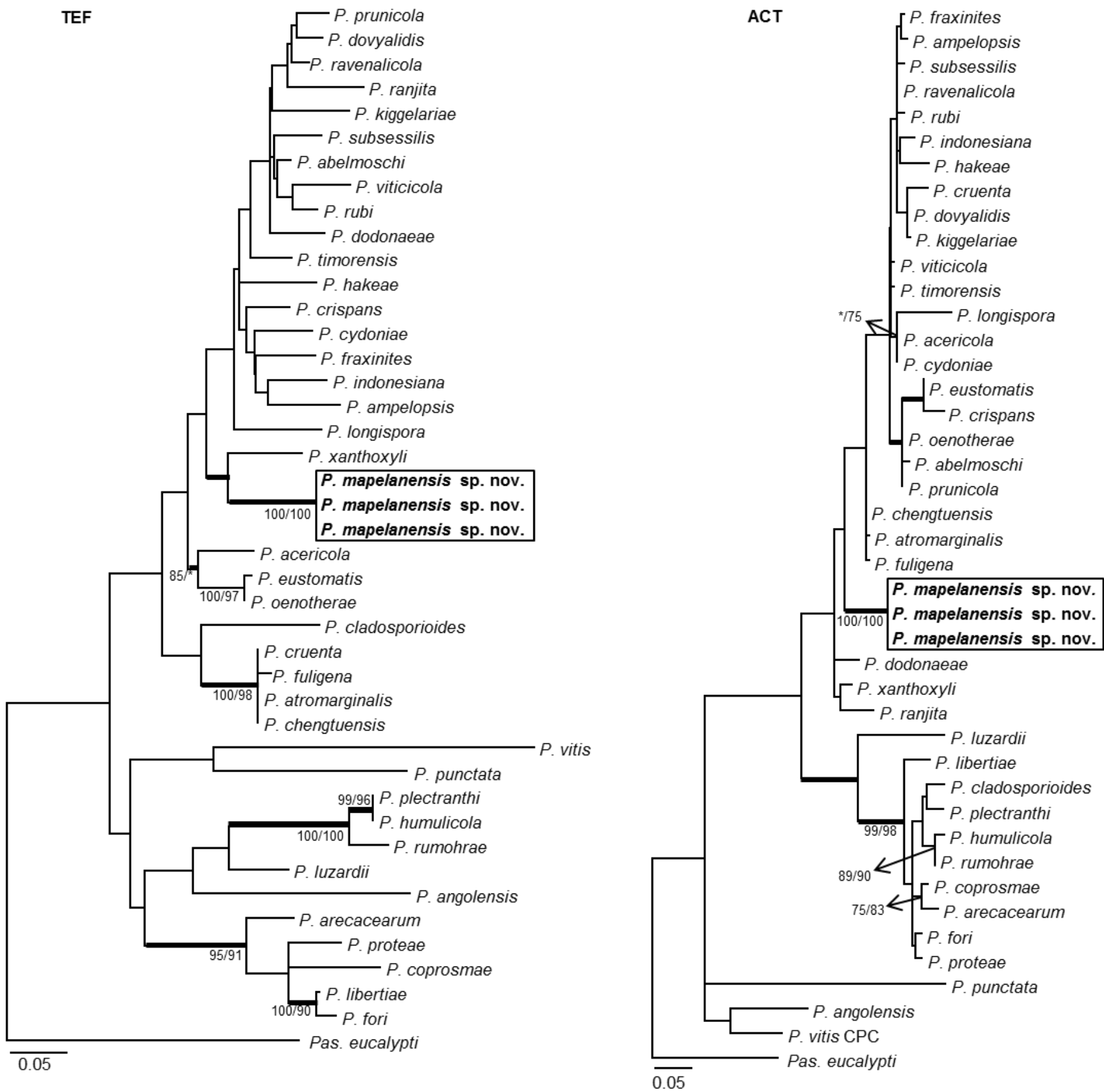

Fig. 4 Phylograms obtained from (BI), (ML) and (MP) analyses of the TEF-1 $\alpha$ and ACT genes. These analyses show $P$. xanthoxyli as the closest relative in TEF and $P$. dodonaeae as the closest species in ACT. These analyses suggest that isolates from $B$. racemosa represent an undescribed species of Pseudocercospora (printed in bold and included in the box). (BI) posterior probabilities $\geq 95 \%$ are represented by thick branches. Bootstrap support values $>70 \%$ are indicated near the nodes as MP/ML. $*$ = bootstrap support values $<70 \%$. 
Pseudocercospora mapelanensis J.A Osorio \& Jol. Roux (Fig. 1, 2)

\section{MycoBank MB 809625.}

Diagnosis: Morphologically akin to Pseudocercospora barringtoniicola, but conidia shorter and wider, (19-)24-38(-45) x (4-)5-7(-10) $\mu \mathrm{m}$, only 1-3-septate, conidiogenous loci sometimes subconspicuous, circle-like in front view, and hila of the conidia often somewhat refractive or even darkened-refractive and thus more conspicuous.

No sexual morph was observed on leaves, fruits or flowers. Leaf spots amphigenous, subcircular to angular-irregular, 2-18 $\mathrm{mm}$ diam or confluent and larger, margin indefinite or surrounded by a diffuse, narrow to wider, paler halo, pale greenish, yellowish to ochraceous. Caespituli amphigenous, also on fruits, punctiform to pustulate, scattered to gregarious, dark brown. Asexual stromata (10-)20-60 $\mu \mathrm{m}$ diam, finally sometimes expanded or confluent and larger, to $100 \mu \mathrm{m}$ diam or even larger, brown to blackish brown, sub-globose, erumpent on leaves and fruits, composed of swollen hyphal cells, subglobose to slightly angular-irregular in outline, 2-6 $\mu \mathrm{m}$ diam, amphigenous, gregarious on both surfaces, denser on the abaxial surface, circular to irregular in shape, at first smaller and substomatal, later expanding or confluent and also immersed, giving rise to conidiophores. Conidiophores (10-)20-116(-136) x (3-)4-7(-8) $\mu \mathrm{m}$, mostly hypophyllous, in small, loose to often large or even very large and dense fascicles, usually arising from a dark stroma, emerging through stomata or erumpent, septate, growing sympodially, moderately to mostly strongly geniculate-sinuous, truncate apex, sometimes obtusely rounded, unbranched, at first sub-hyaline to pale olivaceous, later brownish, ranging from pale to medium olivaceous-brown to brown, wall smooth, thin, to about $0.5 \mu \mathrm{m}$, occasionally somewhat thicker near the base in older conidiophores, to about $1 \mu \mathrm{m}$; conidiogenous cells integrated, terminal or conidiophores reduced to conidiogenous cells, 
conidiogenous loci inconspicuous or subconspicuous by being somewhat refractive around the rim, in from view sometimes visible as minute circle, about 1.5-2 $\mu \mathrm{m}$ diam. Conidia solitary, subcylindrical, fusiform to obclavate, straight to somewhat curved, (19-) 24-38(45) x (4-)5-7(-10) $\mu \mathrm{m}, 1$-3-septate, subhyaline to pale brown or olivacoeus-brown, smooth, thin-walled, apex obtuse and rounded, base short obconically truncate, (1.5-)2(-2.5) $\mu \mathrm{m}$ wide, hila unthickened, usually not darkened, but often somewhat refractive or occasionally even slightly darkened-refractive.

Colonies slow growing (reaching $2 \mathrm{~mm}$ diameter after 15 days, and 5-6 $\mathrm{mm}$ after 30 days) on MEA (Malt Extract Agar) at $25^{\circ} \mathrm{C}$. Colonies with circular to irregular blackish margins, raising centrally, of dense cottony mycelium and hard texture. Young colonies dark, turning to greyish white or green after one month, reverse colony blackish to dark blackish brown. Despite trying different culture media types no sporulation of $P$. mapelanensis was observed in cultures.

Etymology: Epithet refers to one of the areas in South Africa (Mapelane Nature Reserve) where Barringtonia racemosa occurs and where the disease was first observed.

Habitat. Symptomatic fruits, floral sepals and leaves of Barringtonia racemosa.

Known distribution in South Africa: Kwazulu-Natal Province.

Specimens examined. SOUTH AFRICA, KWAZULU-NATAL PROVINCE: Mapelane Nature Reserve, from symptomatic fruits, flowers and leaves. In Herb. PREM (Holotype PREM 61109, Paratype PREM 61107, PREM 61108, col. J.A Osorio \& Jol. Roux). Isotype HAL 2680 F. Other cultures: CMW (Ex-type CMW 40581, Ex-Paratypes CMW 40579, CMW 40580). CBS (ex-type CBS 138923, Ex-Paratype CBS 138922). 
The following is a dichotomous key to Pseudocercospora species on Barringtonia species, adapted by Braun from the Cercosporoid hyphomycetes on Barringtonia spp. (Braun and Mouchacca 2000).

1. Stromata lacking or very small, only with a few substomatal cells; conidiophores in small, loose fascicles, $2-8$, very long, to $185 \mu \mathrm{m}$; on B. acutangulae

P. barringtoniae-acutangulae

$1 *$ Stromata well-developed, about $10-100 \mu \mathrm{m}$ diam ............................................................... 2

2. Conidiophores to $200 \mu \mathrm{m}$ long, pluriseptate; conidia long and narrow, filiform-acicular to narrowly obclavate-cylindrical, $20-90 \times 1.5-5 \mu \mathrm{m}, 2-8$-septate, subhyaline to pale green-olivaceous; on $B$. asiatica

P. barringtoniigena

2* Conidiophores shorter, usually $<100 \mu \mathrm{m}$; conidia obclavate-subcylindrical, fusiform, shorter and broader, about $20-60 \times 4-7(-10) \mu \mathrm{m}$ 3

3. Conidiogenous loci and conidial hila unthickened, neither darkened nor refractive; conidia 30-60 x 4-6.5 $\mu \mathrm{m}, 3-6$-septate; on B. speciosa

\section{P. barringtoniicola}

3* Conidiogenous loci often subconspicuous, visible as minute circle in from view, conidial hila often conspicuous by being somewhat refractive or even darkenedrefractive; conidia shorter, (19-)24-38 x (4-)5-7(-10) $\mu \mathrm{m}$, only 1-3-septate; on $B$. racemosa

P. mapelanensis 


\section{Discussion}

This study provides the first description of a disease of the mangrove associate, $B$. racemosa in South Africa. A fungus in the genus Pseudocercospora was consistently and intimately associated with early symptoms of the disease. It readily sporulated on green tissue and all indications are that this is the causal agent of the disease. The Pseudocercospora sp., was shown to represent a novel taxon for which the name Pseudocercospora mapelanensis has been provided.

Three species of Pseudocercospora have previously been described causing infections on Barringtonia species (Braun et al. 1999, 2000). These include P. barringtoniaeacutangulae U. Braun \& Mouch., P. barringtoniigena U. Braun \& Mouch., and $P$. barringtoniicola U. Braun \& Mouch. Unfortunately neither cultures, sequences nor herbarium specimens are available for these species and they could thus not be included in this study for comparative purposes. However, based on the published descriptions of the symptoms and micro-morphology, these species are all clearly different from $P$. mapelanensis.

Pseudocercospora barringtoniae-acutangulae was first described from B. acutangulae in India causing irregular to sub-circular small leaf spots and later becoming confluent to form large patches on the leaves (Braun and Mouchacca 2000). Pseudocercospora barringtoniigena was reported from B. asiatica in the South Pacific (Futuna) and it is characterized causing sub-circular and amphigenous leaf spots, and similar to $B$. acutangulae in causing large patches on the leaves when lesions become confluent (Braun and Mouchacca 2000). Pseudocercospora barringtoniicola was first described from $B$. speciosa in French Polynesia, Tahiti. This species forms large sub-circular to irregular spots on both sides of the leaves and the lesions become blackish during fungus 
Table 2 Comparison between described species of Pseudocercospora associated with Avicennia marina and Barringtonia species

\begin{tabular}{|c|c|c|c|c|c|}
\hline & Pseudocercospora mapelanensis & $\begin{array}{l}\text { P. barringtoniae- } \\
\text { acutangulae }\end{array}$ & P. barringtoniigena & P. barringtoniicola & P. avicenniae \\
\hline Host Species & B. racemosa & B. acutangulae & B. asiatica & B. speciosa & $\begin{array}{l}\text { Avicennia marina } \\
\text { (Acanthaceae) }\end{array}$ \\
\hline $\begin{array}{l}\text { Conidiophores } \\
\qquad(\mu \mathrm{m})\end{array}$ & $\begin{array}{c}(10-) 20-116(-136) \times(3-) 4-7(-8) \\
\text { pluriseptate }\end{array}$ & $\begin{array}{l}30-185 \times(3-) 4-7 \\
2-6 \text { septa }\end{array}$ & $\begin{array}{l}20-200 \times 3-7 \\
\text { pluriseptate }\end{array}$ & $\begin{array}{l}10-50 \times 3-6 \\
0-3 \text { septa }\end{array}$ & $20-90 \times 3-5.5$ \\
\hline Conidia $(\mu \mathrm{m})$ & $\begin{array}{c}(19-) 24-38(-45) \times(4-) 5-7(-10) \\
(0-) 1-3(-4) \\
\text { septate }\end{array}$ & $\begin{array}{c}20-70(-85) \times 4-4.5-7(-8) \\
1-6(-7) \text { septate }\end{array}$ & $\begin{array}{l}20-90 \times 1.5-5 \\
2-8 \text {-septate }\end{array}$ & $\begin{array}{l}30-60 \times 4-6.5 \\
3-6 \text { septate }\end{array}$ & $\begin{array}{l}30-100 \times 3-5 \\
3-12 \text {-septate }\end{array}$ \\
\hline Region & $\begin{array}{l}\text { South Africa } \\
\text { and Richards Bay) }\end{array}$ & $\begin{array}{c}\text { India } \\
\text { (Uttar Pradesh, Gorakhpur) }\end{array}$ & $\begin{array}{l}\text { South Pacific } \\
\text { (Futuna) }\end{array}$ & $\begin{array}{l}\text { French Polynesia, } \\
\text { Tahiti, Rurutu }\end{array}$ & Australia \\
\hline Reference & Current study & $\begin{array}{c}\text { Braun \& Mouchacca } \\
2000\end{array}$ & Braun \& Mouchacca 2000 & $\begin{array}{c}\text { Braun et al. } \\
1999\end{array}$ & Shivas et al. 2009 \\
\hline
\end{tabular}


fructification (Braun et al. 1999). Based on morphological descriptions provided for these fungi they differ from the South African fungus in a number of characteristics (Table 2). Conidiophores and conidia of $P$. barringtoniae-acutangulae and $P$. barringtoniigena are larger than those of $P$. mapelanensis. Conidiophores of $P$. barringtoniicola are shorter, and conidia larger, than those of $P$. mapelanensis. Species previously described from Barringtonia also differ in the number of conidial septa, with $P$. mapelanensis having between one and three septa while the other species have more than three transverse septa.

Sequence data for the Pseudocercospora species known to occur on Barringtonia are not available for comparison and the lack of cultures preclude this work. However, multiple phylogenetic analyses showed that $P$. mapelanensis is most closely related to, but distinct from, P. dodonaeae Boesewinkel, P. longispora Arzanlou \& Crous, and P. xanthoxyli (Cooke) Y.L. Guo \& X.J. Liu. Based on multiple phenotypic characters such as conidial and conidiophores shape, dimensions and number of septa, these species can also be distinguished from $P$. mapelanensis.

It was not possible to conduct pathogenicity tests with $P$. mapelanensis in this study. This was due to the fact that the fungus does not sporulate in culture and the host trees are rare and could not be obtained for intensive study. However, all aspects of infections indicated that this is a highly host specific fungus, sporulating on freshly infected green tissue. This is consistent with many Pseudocercospora species and their Mycosphaerella sexual states that are highly host-specific and that are commonly treated as pathogens in the absence of pathogenicity tests (Crous and Braun 2003, Crous et al. 2004, Burguess et al. 2007, Crous et al. 2008, Crous 2009). All indications from this study are that $P$. mapelanensis is the causal agent of the disease of $B$. racemosa and it was the only fungus found consistently on infected tissue. The disease of B. racemosa was often severe and although it did not 
cause defoliation, it appeared to result in significant levels of fruit abortion. It is probable that the pathogen is native on its host but this is a question that deserves further study.

\section{Acknowledgements}

This work was financially supported by the Department of Science and Technology (DST) and National Research Foundation (NRF) Center of Excellence in Tree Health Biotechnology (CTHB). We thank Ezemvelo KZN Wildlife and the Isimangaliso Wetland Park for sampling permits and assistance in the field. The material was collected under EKZNW permit no OP 4776. The authors gratefully acknowledge Prof. dr U. Braun (Martin-Luther-University, Institute of Biology, Halle, Germany), for his assistance in revising the fungal material and for his valuable input in the diagnosis of the new Pseudocercospora species. We also acknowledge Ariska Van der Nest, Arista Fourie and James Mehl (FABI, University of Pretoria), for technical assistance.

\section{References}

Barnard EL, Freeman TE (1982) Cylindrocarpon galls on red mangrove. Plant Pathology $235: 1-2$

Braun U, Mouchacca J, McKenzie EHC (1999) Cercosporoid hyphomycetes from New Caledonia and some other South Pacific islands. New Zealand Journal of Botany $37: 297-327$

Braun U, Mouchacca J (2000) Cercosporoid hyphomycetes on Barringtonia species. Sydowia 52:73-77 
Burgess TI, Barber PA, Sufaati S, Xu D, Hardy GE, Dell B (2007) Mycosphaerella spp. on Eucalyptus in Asia; new species; new hosts and new records. Fungal Diversity $24: 35-157$

Carbone I, Kohn LM (1999) A method for designing primer sets for speciation studies in filamentous ascomycetes. Mycologia 91:553-556

Chantaranothai P (1995) Barringtonia (Lecythidaceae) in Thailand. Kew Bulletin. 50:677694

Crous PW, Braun U (2003) Mycosphaerella and its anamorphs. CBS Biodiversity Series. Centraalbureau voor Schimmelcultures, Utrecht, Netherlands 1:1-571

Crous PW, Groenewald JZ, Pongpanich K, Himaman W, Arzanlou M, Wingfield MJ (2004) Cryptic speciation and host specificity among Mycosphaerella spp. occurring on Australian Acacia species grown as exotics in the tropics. Studies in Mycology 50:457-469

Crous PW, Summerell BA, Mostert L, Groenewald JZ (2008) Host specificity and speciation of Mycosphaerella and Teratosphaeria species associated with leaf spots of Proteaceae. Persoonia 20:59-86

Crous PW (2009) Taxonomy and phylogeny of the genus Mycosphaerella and its anamorphs. Fungal Diversity 38:1-24

Ellison AM, Farnsworth EJ (2001) Mangrove communities. In Marine Community Ecology. M.D. Bertness, S.D. Gaines and M.E. Hay, Eds, Sinauer Associates, Sunderland, MA, USA. 16, 423-442 
Guindon S, Gascuel O (2003) A simple, fast and accurate method to estimate large phylogenies by maximum-likelihood. Systematic Biology 52:696-704

Hogarth PJ (2007) The biology of mangroves and seagrasses. Second edition. Oxford University Press. ISBN 978-0-19-856870-4 (Hbk)

Jacobs K, Bergdahl DR, Wingfield MJ, Halik S, Seifert KA, Bright DE, Wingfield BD (2004) Leptographium wingfieldii introduced into North America and found associated with exotic Tomicus piniperda and native bark beetles. Mycological Research 108:411-418

Kathiresan K, Bingham BL (2001) Biology of mangroves and mangrove ecosystems. Advances in Marine Biology 40:84-193

Katoh K, Misawa K, Kuma Ki, Miyata T (2002) MAFFT: A novel method for rapid multiple sequence alignment based on fast Fourier transform. Nucleic Acids Research 30:3059-3066

Lim TK (2012) Barringtonia racemosa. Edible Medicinal and Non-Medicinal Plants $3: 114-121$

Moncalvo JM, Rehner SA, Vilgalys R (1993) Systematics of Lyophyllum section Difformia based on evidence from culture studies and ribosomal DNA sequences. Mycologia 85:788-794

Osorio JA, Wingfield MJ, Roux J (2014) A review of factors associated with decline and death of mangroves, with particular reference to fungal pathogens. South African Journal of Botany doi.org/10.1016/j.sajb.2014.08.010 
Posada D (2008) jModelTest: Phylogenetic Model Averaging. Molecular Biology and Evolution 25:1253-1256

Raeder U, Broda P (1985) Rapid preparation of DNA from filamentous fungi. Letters in Applied Microbiology 1:17-20

Rayner, RW (1970) A mycological colour chart. Kew, Surrey, UK: CMI and British Mycological Society

Ronquist F, Teslenko M, van der Mark P, et al. (2012) MrBayes 3.2: efficient Bayesian phylogenetic inference and model choice across a large model space. Systematic Biology 61:539-542

Shivas RG, Young AJ, Crous PW (2009) Pseudocercospora avicenniae. Persoonia 23:192-193

Swofford DL (2003) PAUP*. Phylogenetic Analysis Using Parsimony (*and Other Methods). Version 4. Sinauer Associates, Sunderland, Massachusetts. ed.^eds.), p.^pp. Sinauer Associates, Sunderland, Massachusetts

Spalding M, Kainume M, Collins L (2010) World Atlas of Mangroves. The Nature Conservancy. International Society for Mangrove Ecosystems 1-304.

Tamura K, Stecher G, Peterson D, et al. (2013) MEGA6: molecular evolutionary genetics analysis version 6.0. Molecular Biology and Evolution 30:2725-2729

Tattar TA, Scott DC (2004) Dynamics of tree mortality and mangrove recruitment within black mangrove die-offs in Southwest Florida. Final report University of Massachusetts 1-13

Teas HJ, McEwan RJ (1982) An epidemic dieback gall disease of Rhizophora mangroves in The Gambia, West Africa. Plant Disease 66:522-523 
Tomlinson PB (1986) The botany of mangroves. Cambridge University Press. Cambridge, U.K. 413 pp

USDA, ARS, National genetic resources program. Germplasm resources information network - (GRIN) online database. National germplasm resources laboratory, Beltsville, $\quad$ Maryland. URL: http://www.ars-grin.gov/cgiin/npgs/html/taxon.pl?6514 (10 December 2014)

Vilgalys R, Hester M (1990) Rapid genetic identification and mapping of enzymatically amplified ribosomal DNA from several Cryptococcus species. Journal of Bacteriology 172:4238-4246

Wang L, Mu M, Li X, Lin P, Wang W (2011) Differentiation between true mangroves and mangrove associates based on leaf traits and salt contents. Journal of Plant Ecology $4: 292-301$

Wier AM, Tattar TA, Klekowski EJ (2000) Disease of mangrove (Rhizophora mangle) in Southwest Puerto Rico caused by Cytospora rhizophorae. Biotropica 32:299-306

White TJ, Bruns T, Lee S, Taylor J (1990) Amplification and direct sequencing of fungal ribosomal RNA genes for phylogenetics. In: PCR Protocols: a guide to methods and applications (Innis MA, Gelfand DH, Sninsky JJ, White TJ, eds). Academic Press, San Diego, California 315-322 